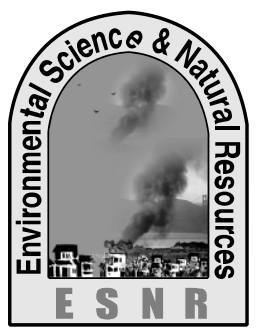

\title{
Status and Spatial Variability of Trace Elements in the Low Ganges River Floodplain Soils of Bangladesh
}

\author{
M. D. Islam ${ }^{1}$, M. M. $\operatorname{Rahman}^{1 *}$, M. H. Kabir ${ }^{1}$, G. K. M. M. Rahman' and M. S. Hossain ${ }^{2}$ \\ ${ }^{1}$ Department of Soil Science, Bangabandhu Sheikh Mujibur Rahman Agricultural University, \\ Gazipur-1706, Bangladesh \\ ${ }^{2}$ Department of Soil Science, Sylhet Agricultural University \\ *Corresponding author: mizan@bsmrau.edu.bd
}

\begin{abstract}
Soils of the Low Ganges River Floodplain encroaching Faridpur district of Bangladesh have immense contribution to crop production, while little information available focusing the spatial variability of trace elements in the area. Therefore, the study was conducted to quantify the trace elements collecting a total of 122 representative soil samples from rice fields of Faridpur district. Soil samples were analyzed and found that $\mathrm{Cu}, \mathrm{Fe}, \mathrm{Mn}, \mathrm{Zn}$ and $\mathrm{B}$ were ranged from 0.80-6.80, 24-295, 10-129, 0.12-2.20 and 0.5-9.05 ppm, respectively. The pollution indexes are noteworthy features which revealed that only Mn may exhibit a risk for environmental pollution. The concentrations of trace elements, $\mathrm{pH}$ and organic carbon in soils displayed a significant spatial diversity because of anthropogenic and geogenic contribution. The distribution maps of soil $\mathrm{pH}$, organic carbon and trace elements might be useful to farmers, researchers and planners in designing and planning agricultural programs in the study area.
\end{abstract}

Key words: Ganges river floodplain, Spatial variability and Trace elements

\section{Introduction}

Availability of trace elements in soil affects crop growth, yield and quality directly. Some trace elements are heavy metals which may cause soil pollution if their concentrations in soils are excessively high. Study on spatial distribution of trace elements and their influencing factors are needed for effective management and protection of soil. Almost all soil nutrients including trace elements exhibit variability because of the dynamic interactions among the soil forming factors acting in different production environments or agroecological regions (Jenny, 1941). Bangladesh is divided into three broad physiographical units and thirty agroecological zones. The floodplain is one of the physiographical units comprising $80 \%$ of the total area of the country and nutrient contents including the trace elements varied significantly in different floodplains soils (Brammer, 2012). The Ganges Floodplain in Bangladesh represents a typical riverine landscape which covers about one-fifth of its total land area (BARC, 2012). The soils in the floodplain are known to be productive. However, with the intensification of agriculture, these soils have witnessed depletion of essential nutrients in Bangladesh soils which first appeared in 1960s following the introduction of high yielding rice varieties together with the excessive use of inorganic fertilizers (Islam, 1992). Although trace elements are needed by plants in only very small quantities their deficiencies in soils may result in severe reduction of plant growth and development as well as total crop failure (Cheng et al., 2013). Trace elements such as $\mathrm{Cu}, \mathrm{Fe}, \mathrm{Mn}, \mathrm{Zn}, \mathrm{B}, \mathrm{Ni}$ and $\mathrm{Pb}$ are potential soil pollutants. Soils consist of heterogeneous mixtures of organic and inorganic solid components as well as a variety of soluble substances. Thus, it is important to evaluate the spatial distribution of trace elements to establish soil management guidelines for potential toxic hazards and to understand chemical behavior and fate of trace elements in soils (Singh et al., 2005; Krishna et al., 2008). The distribution of trace elements in the Ganges Floodplain soil is not uniform and well documented. This problem deserves special attention for its sustainable development. Few sporadic studies dealing with the variability of trace elements of the soils and sediments of the Gangetic alluvium in Bangladesh and India have been reported. Hence, more study is needed to know the trace elements variability of that soil and understand the soil productivity and also to understand the mineral transformations and degree of soil development. Since the floodplain soils are intensively used for growing paddy rice, the spatial variability of selected soil trace elements should be thoroughly studied for better understanding of maintaining sustainability in soil health as well as crop production. In recent years, the study of available trace nutrient has attracted more attention (Zhang et al., 2005; Bityutskii et al., 2012). Keeping the above views in mind the present study was undertaken to determine $\mathrm{pH}$, organic carbon, copper, iron, manganese, zinc and boron contents and produce spatial distribution maps of the Low Ganges River Floodplain soils in the Faridpur district of Bangladesh.

\section{Materials and Methods}

The study was conducted in the Low Ganges River Floodplain agroecological zone encroaching Faridpur district of Bangladesh within $23.04^{0}-23.41^{0} \mathrm{~N}$ latitude and $89.00^{\circ}-90.08^{0}$ E longitude (Fig. 1). All eight upazilas of Faridpur district viz. Faridpur Sadar, Alfadanga, Nagarkanda, Sadarpur, Char Bhadrasan, Bhanga, Boalmari and Madhukhali were considered for soil sampling sites (Fig. 2). The major land types of the study area were medium high, medium low and low where the cropping patterns were Boro - T. aman fallow for the first one and Boro - fallow - fallow for the second and third. Boro and transplanted aman ( $\mathrm{T}$. aman) are two major rice in Bangladesh. Boro rice is cultivated in the dry season under full irrigation, while T. aman cultivated in the monsoon as mainly rainfed crop or supplemented by partial irrigation if needed. 


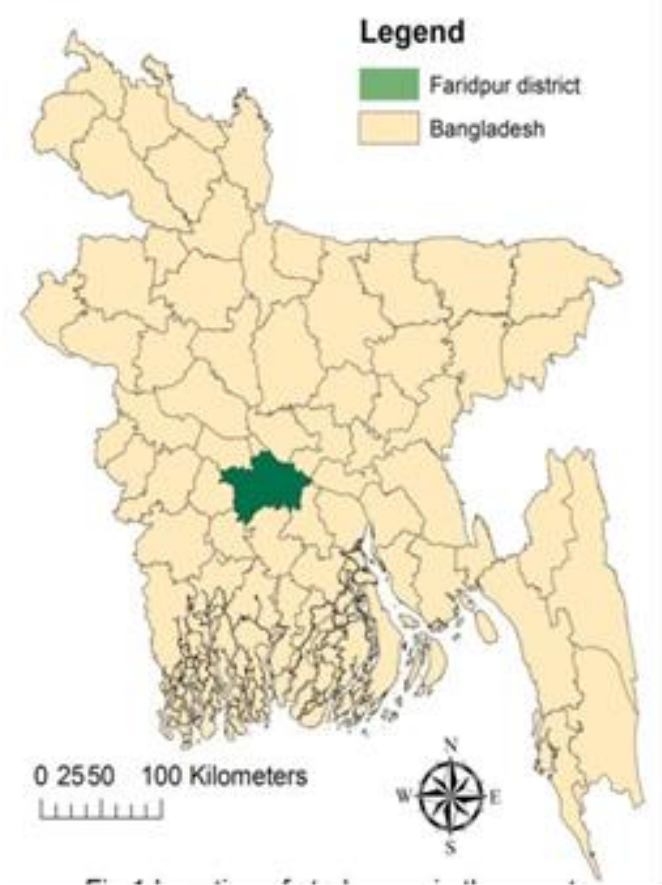

Fig. 1. Study area in map of Bangladesh

A total of 122 representative soil samples from the above mentioned upazilas were collected following standard protocol (BARC, 2012). An equal sampling distance among sampling points were possibly maintained. Latitudes and longitudes of each sampling points were recorded using global positioning system (GPS). Soil samples were collected from 4 x $4 \mathrm{~km}$ grid from rice - rice cropping pattern and those points were plotted in the upazila map along with the mouza before going to sampling. If any point did not match with ricerice system then nearest mouza with rice-rice cropping pattern was selected. From each of the selected mouza, three soil samples were collected diagonally considering 0-20 cm depth: one from near, one from middle and other from the tail end of the command area. Each sample was the composite of three subsamples and GPS value was taken from the middle of the sub- samples. Information such as depth, cropping pattern, land type, etc of the sampling fields were also recorded.

The collected soil samples were air dried, sieved using $2 \mathrm{~mm}$ mesh sieve and kept in plastic pots with proper labeling. Soil pH was determined by Glass Electrode $\mathrm{pH}$ meter method, organic carbon by wet oxidation method, boron by Azomethine $\mathrm{H}$ colorimetric method and manganese, copper, zinc and iron by di-acid digestion method (Page et al., 1982).

Pollution indexes (PIs) for each $\mathrm{Cu}, \mathrm{Fe}, \mathrm{Mn}$ and $\mathrm{Zn}$ were calculated using the ratio of its measured minimum and maximum concentrations (Cs) to the background concentration $(\mathrm{Cb})$ in soil as mentioned below (Chen et al., 2005; Wei and Yang, 2010):

$\mathrm{PI}=C s / C b$

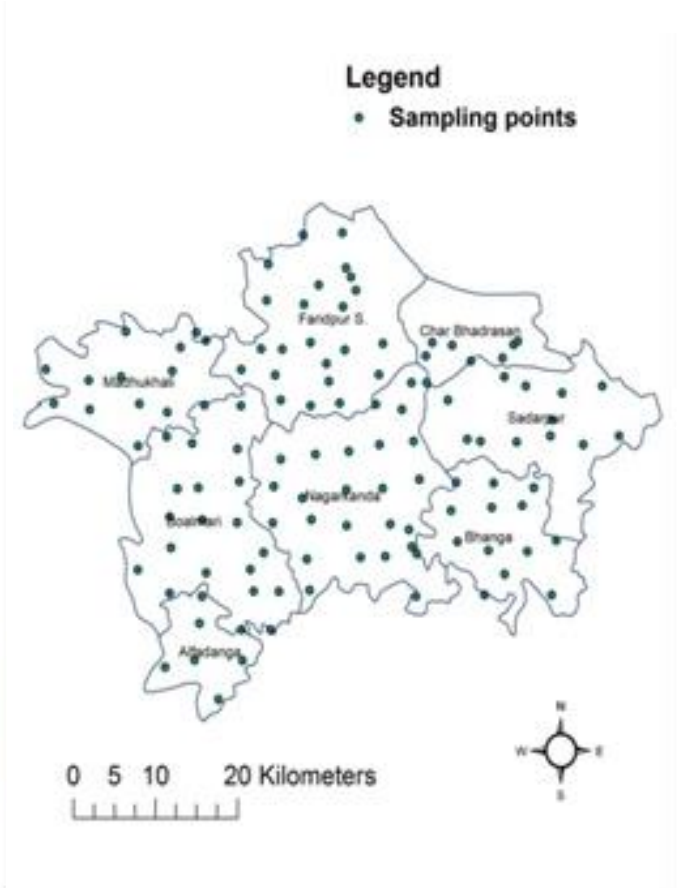

Fig. 2. Study area showing sampling points

Where, the units of $\mathrm{Cs}$ and $\mathrm{Cb}$ were $\mathrm{ppm}$. The soil background values of $\mathrm{Zn}$ and $\mathrm{Cu}$ were considered 86.5 and $31.1 \mathrm{ppm}$, respectively (CNEMC, 1990), while for $\mathrm{Fe}$ and $\mathrm{Mn}$ the values were $3700 \mathrm{ppm}$ (Silva, 1996) and 100 ppm (Bowen 1966), respectively. The PI for metals were classified as low $(\mathrm{PI} \leq 1)$, medium $(1<\mathrm{PI} \leq 3)$ and high contamination (PI > 3).

All statistical analyses in this study were performed using SPSS software version 16.0 and Microsoft Excel. All the distribution maps of trace metals were prepared using the Arc GIS software.

\section{Results and Discussion}

\section{Soil pH}

Soil $\mathrm{pH}$ was found neutral to slightly alkaline where the minimum and maximum values were recorded 6.75 and 8.39 in Nagarkanda and Faridpur sadar upazil, respectively (Table 1 and 2). Soil $\mathrm{pH}$ of the Low Ganges River Floodplain is varied from neutral to alkaline in range (BARC, 2012). The soil $\mathrm{pH}$ was found greater than 8.0 in the northeastern part of Bhanga, some part of Boalmari and Sadarpur upazila. On the other hand the lowest $\mathrm{pH}$ value was found in very small portion of the Boalmari upazila with $\mathrm{pH}$ less than 7.0 (Fig. 3). The most of the area of Faridpur district was found slightly alkaline having a soil $\mathrm{pH}$ range of 7.58.0. The soil $\mathrm{pH}$ has the greatest effect on the availability of trace metals in soil (Sauve et al., 1997). The $\mathrm{pH}$ values with the ranges of 7.0-7.5 were found in most of the area of Nagarkanda and parts of Boalmari, Madhukhali and Faridpur sadar. Correlation coefficients indicated a moderate negative correlation between soil $\mathrm{pH}$ and all trace metals. In general, availability of trace elements in soils increases with the decrease of soil $\mathrm{pH}$. 


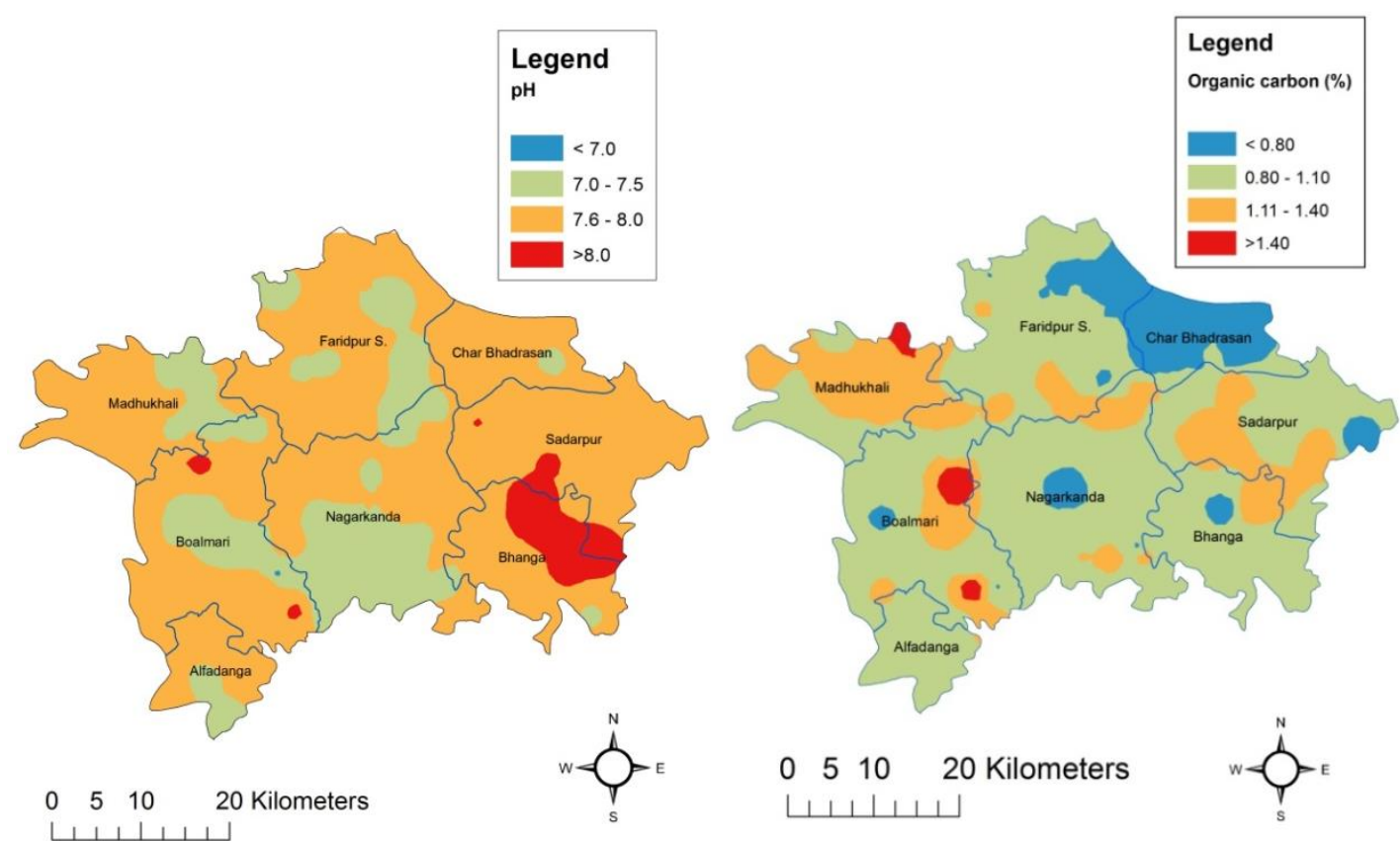

Fig. 3. Spatial distribution of $\mathrm{pH}$ in soils of Faridpur

Fig. 4. Spatial distribution of organic carbon in soils of Faridpur

Table 1. Minimum, maximum and mean values of different elements in soils collected from Faridpur district under Low Ganges River Floodplain agroecological zone

\begin{tabular}{lcccc}
\hline Elements & Minimum & Maximum & Mean \pm S.D. & Pollution index (PI) \\
\hline $\mathrm{pH}$ & 6.75 & 8.39 & $7.65 \pm 0.42$ & - \\
$\mathrm{OC} \%$ & 0.21 & 2.31 & $0.99 \pm 0.34$ & $0.03-0.22$ \\
$\mathrm{Cu}\left(\mathrm{mg} \mathrm{kg}^{-1}\right)$ & 0.80 & 6.80 & $3.12 \pm 1.14$ & $0.01-0.08$ \\
$\mathrm{Fe}\left(\mathrm{mg} \mathrm{kg}^{-1}\right)$ & 23.90 & 295.24 & $117.53 \pm 52.52$ & $0.10-1.29$ \\
$\mathrm{Mn}\left(\mathrm{mg} \mathrm{kg}^{-1}\right)$ & 9.53 & 128.92 & $57.78 \pm 18.51$ & $0.001-0.03$ \\
$\mathrm{Zn}\left(\mathrm{mg} \mathrm{kg}^{-1}\right)$ & 0.12 & 2.20 & $0.65 \pm 0.40$ & - \\
$\mathrm{B}\left(\mathrm{mg} \mathrm{kg}^{-1}\right)$ & 0.52 & 9.05 & $3.62 \pm 1.91$ & \\
\hline
\end{tabular}

The area having calcareous in nature impedes phosphorus availability and thereby appeared as one of the problem soils in Bangladesh. In calcareous soils, inherent soil phosphorus or phosphorus applied as inorganic fertilizer might react with available calcium in soils and form insoluble calcium phosphate and thus gradually $\mathrm{P}$ availability reduces in soils for plant uptake. Therefore, phosphorus deficiency symptoms exhibited in plants, which need to be addressed through adoption of different management practices especially in the upland. Organic matter is considered as an inhibitor of $\mathrm{P}$ fixation in some extent and therefore, regular application of different available organic manures, composts, biochars and even green manuring is recommended to increase organic matter levels in soils. von Wandruszka (2006) reported that swine and chicken manure are rich in $\mathrm{P}$ and therefore, application of manures supply and mobilize $\mathrm{P}$ in soils. Organic acids released from organic matter block $\mathrm{P}$ sorption sites and form complex with exchangeable $\mathrm{Al}$ and $\mathrm{Fe}$ in the soil, which enhances $\mathrm{P}$ mobilization in soils. Periodic soil test for $\mathrm{P}$ and subsequent $\mathrm{P}$ fertilizer application may also be recommended in calcareous soils. In wetland rice culture such $\mathrm{pH}$ is not a problem because of carbon dioxide absorption and subsequent drop down of $\mathrm{pH}$ from alkaline to neutral state.

\section{Organic carbon contents}

Organic carbon contents in soils of different upazila under Faridpur district were found in a wider range which varied from very low $(0.21 \%)$ to very high $(2.31 \%)$ in Sadarpur and Boalmari upazila, respectively (Table 1 and 2). Organic carbon contents were found very low to low in ridges and medium to high/very high in basin areas. The study area comprises the eastern half of the Ganges River Floodplain which is low lying and therefore, organic matter content is generally found medium (BARC, 2012). General soil fertility of the Low Ganges River Floodplain region is medium, except phosphorus, which is low and obvious in calcareous soils. The concentration of organic carbon with the range of $>1.40 \%$ was found in some northern part of Madhukhali and some eastern and southeastern part of Boalmari upazila (Fig. 4). This high level of organic carbon in soils is attributed from accumulation of runoff materials and other organic constituents. Land types of the above mentioned upazilas are mainly medium low and low where basin area receives organic materials from the upper ridge areas, therefore, soil becomes 
enriched with organic matter. Such findings are

endorsed

by

Franzluebbers

(2010).

Table 2. Minimum, maximum and mean values of different elements in soils collected from different upazila of Faridpur district

\begin{tabular}{|c|c|c|c|c|c|c|c|c|}
\hline \multirow[t]{2}{*}{ Upazila } & \multirow[t]{2}{*}{ Statistics } & \multicolumn{7}{|c|}{ Properties of soils in different upazila under Faridpur district } \\
\hline & & $\mathrm{pH}$ & $\begin{array}{l}\mathrm{OC} \\
(\%)\end{array}$ & $\mathrm{Cu}$ & $\mathrm{Fe}$ & $\begin{array}{l}\mathrm{Mn} \\
(\mathrm{mg} / \mathrm{kg})\end{array}$ & $\mathrm{Zn}$ & B \\
\hline \multirow[t]{2}{*}{ Faridpur sadar } & Min & 6.89 & 0.55 & 1.20 & 39.20 & 28.39 & 0.32 & 1.18 \\
\hline & $\begin{array}{l}\text { Max } \\
\text { Mean }\end{array}$ & $\begin{array}{l}8.39 \\
7.66\end{array}$ & $\begin{array}{l}1.35 \\
0.92\end{array}$ & $\begin{array}{l}6.00 \\
3.43\end{array}$ & $\begin{array}{l}198.47 \\
107.73\end{array}$ & $\begin{array}{l}75.35 \\
51.73\end{array}$ & $\begin{array}{l}2.20 \\
0.64\end{array}$ & $\begin{array}{l}4.95 \\
2.61\end{array}$ \\
\hline \multirow[t]{3}{*}{ Alfadanga } & Min & 7.01 & 0.64 & 1.60 & 46.64 & 57.78 & 0.20 & 2.71 \\
\hline & $\operatorname{Max}$ & 8.21 & 1.29 & 4.40 & 212.81 & 71.42 & 0.80 & 6.55 \\
\hline & Mean & 7.76 & 0.92 & 3.01 & 96.96 & 63.57 & 0.42 & 3.69 \\
\hline \multirow[t]{3}{*}{ Madhukhali } & Min & 6.85 & 0.66 & 1.60 & 23.90 & 43.12 & 0.16 & 1.82 \\
\hline & $\operatorname{Max}$ & 8.12 & 2.17 & 6.80 & 295.24 & 128.92 & 1.28 & 8.12 \\
\hline & Mean & 7.52 & 1.20 & 3.39 & 133.53 & 70.99 & 0.44 & 4.09 \\
\hline \multirow{3}{*}{ Char Bhadrasan } & Min & 7.12 & 0.34 & 1.00 & 47.58 & 29.04 & 0.44 & 1.35 \\
\hline & Max & 8.20 & 0.78 & 2.40 & 132.58 & 66.77 & 1.50 & 4.14 \\
\hline & Mean & 7.67 & 0.61 & 1.83 & 100.20 & 43.85 & 0.84 & 2.57 \\
\hline \multirow[t]{3}{*}{ Sadarpur } & Min & 7.41 & 0.21 & 1.20 & 59.50 & 9.53 & 0.40 & 0.93 \\
\hline & Max & 8.10 & 1.82 & 4.00 & 198.65 & 85.06 & 1.36 & 8.07 \\
\hline & Mean & 7.91 & 1.09 & 2.55 & 117.50 & 42.26 & 0.65 & 3.39 \\
\hline \multirow{3}{*}{ Boalmari } & Min & 6.88 & 0.57 & 2.00 & 72.89 & 28.00 & 0.22 & 1.35 \\
\hline & Max & 8.24 & 2.31 & 4.80 & 280.42 & 63.02 & 1.80 & 6.13 \\
\hline & Mean & 7.66 & 1.11 & 2.91 & 154.91 & 49.31 & 0.63 & 3.64 \\
\hline \multirow[t]{3}{*}{ Nagarkanda } & Min & 6.75 & 0.46 & 0.80 & 33.29 & 29.48 & 0.12 & 1.56 \\
\hline & Max & 8.07 & 1.42 & 6.80 & 195.65 & 93.13 & 2.20 & 9.05 \\
\hline & Mean & 7.45 & 0.94 & 3.03 & 103.92 & 69.68 & 0.76 & 4.33 \\
\hline \multirow[t]{3}{*}{ Bhanga } & Min & 7.18 & 0.25 & 2.20 & 58.24 & 15.40 & 0.48 & 0.52 \\
\hline & $\operatorname{Max}$ & 8.34 & 1.57 & 6.00 & 189.49 & 78.36 & 1.52 & 11.54 \\
\hline & Mean & 7.88 & 1.02 & 3.93 & 118.84 & 57.64 & 0.81 & 4.19 \\
\hline
\end{tabular}

The lowest organic carbon contents $(<0.80 \%)$ was found in case of whole of Char Bhadrasan, very small part of Bhanga, Faridpur Sadar, Sadarpur, Nagarkanda and Boalmari upazila. The land types of these upazilas are mainly medium high and from this area organic materials are washed out and thus attributed comparatively to lower organic carbon than that of medium low and low lands. The organic carbon with the range of $1.11-1.40 \%$ was found in greater part of Madhukhali, some part of Bhanga, Faridpur Sadar, Sadarpur, Nagarkanda and Boalmari upazila. Organic carbon contents were found low to medium in a larger area of Faridpur district, where OC concentrations were ranged from $0.80 \%$ to $1.10 \%$ in the whole Alfadanga, most of the parts of Bhanga, Faridpur Sadar, Sadarpur, Nagarkanda and Boalmari upazila (Fig. 4). Organic matter plays a significant role in nutrient availability in soils. Organic carbon with iron and copper were found positively correlated, while the increment of organic carbon in soils was found nonresponsive to manganese, zinc and boron (Table 3). Halim et al. (2003) reported that decomposition of organic matter forms organic anions which may form metal complexes, thus it can either reduce metal availability in soil or increase through solubilization of the complexes in favorable soil environment.

Table 3. Different trace elements concentration under different category of organic carbon in Low Ganges River Floodplain soils

\begin{tabular}{lccc}
\hline Elements $\left(\mathrm{mg} \mathrm{kg}^{-1}\right)$ & \multicolumn{3}{c}{ Category of OC $(\%)$} \\
\cline { 2 - 4 } & $<1.0$ & $1-1.5$ & $>1.5$ \\
\hline $\mathrm{Cu}$ & 2.82 & 3.53 & 3.58 \\
$\mathrm{Fe}$ & 113.16 & 121.46 & 135.21 \\
$\mathrm{Mn}$ & 56.80 & 61.08 & 53.18 \\
$\mathrm{Zn}$ & 0.67 & 0.64 & 0.58 \\
$\mathrm{~B}$ & 3.65 & 3.64 & 3.38 \\
\hline
\end{tabular}

Trace element concentrations and spatial distribution
Concentrations of $\mathrm{Cu}, \mathrm{Fe}, \mathrm{Mn}, \mathrm{Zn}$ and $\mathrm{B}$ in the soils of Low Ganges River Floodplain in Faridpur district 
varied from very low to very high (Table 1 and 2). The fashion of element variations depends on Floodplain ridges and basins, land types, irrigation, fertilization and other soil and crop management practices.

The concentrations of $\mathrm{Cu}$ varied from 0.80 to $6.80 \mathrm{ppm}$ with an average value of $3.12 \mathrm{ppm}$ (Table 1 and 2). In soil fertility ranking provided by BARC (2012) it is mentioned that copper content when crossed $0.75 \mathrm{ppm}$ it is ranked as very high. As minimum copper content in soils of the Low Ganges River Floodplain was found $0.80 \mathrm{ppm}$, therefore, its fertility might be rated as very high. The highest of $\mathrm{Cu}$ concentration $(>5.6 \mathrm{ppm})$ was found in a small area of northern part of Nagarkanda (Fig. 5). In the whole of Char Bhadrasan, middle of
Nagarkanda and eastern part of Sadarpur upazila $\mathrm{Cu}$ contents were $<2.4 \mathrm{ppm}$ (Fig. 5). The overall $\mathrm{Cu}$ concentration was very high in whole study area due to discharge of maximum dissolved $\mathrm{Cu}$ on the surface soil and due to lithogenic sources and dumping of industrial wastes and also due to unclassified anthropogenic actions. Occurrence of higher concentration of $\mathrm{Cu}$ in the underground irrigation water can also be attributed to the high level of copper in the area. Natural weathering of soil and discharges from industries and sewagetreatment plants might have positive contribution to higher copper contents in the study area of Low Ganges River Floodplain area (Hutchinson, 1988; Wu et al., 2001).

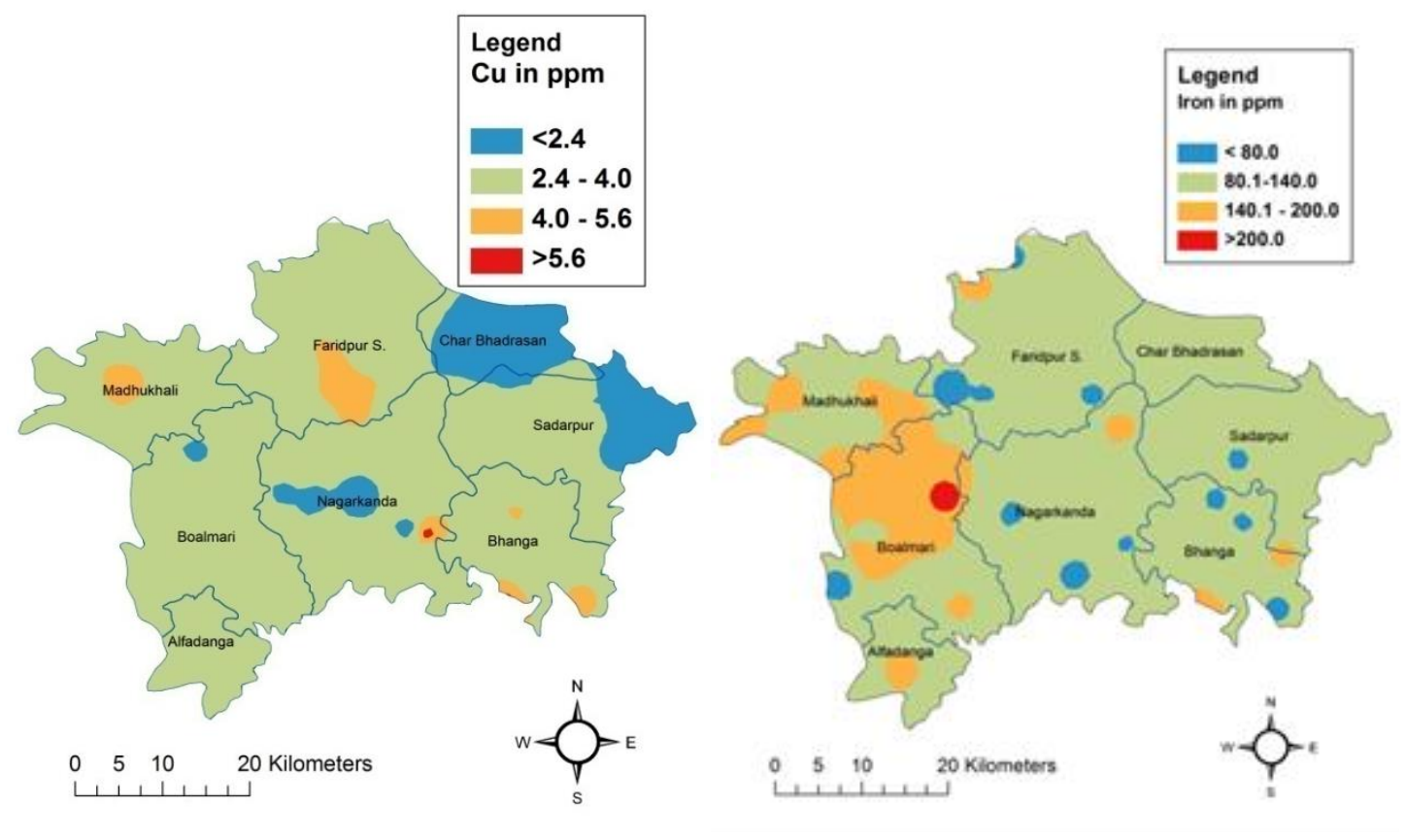

Fig. 5. Spatial distribution of Copper in soils of Faridpur district Fig. 6. Spatial distribution of Iron in soils of Faridpur

The iron concentrations varied from 24 to $295 \mathrm{ppm}$ with an average value of $118 \mathrm{ppm}$ where both minimum and maximum values were observed in soils of Madhukhali upazila (Table 1 and 2). Iron contents are considered very high when its concentrations exceeded $15 \mathrm{ppm}$ (BARC, 2012). The both minimum (24 ppm) and maximum (295 ppm) concentrations of $\mathrm{Fe}$ in soils of the Low Ganges River Floodplain region were found in the southwestern and northern part of Boalmari upazila (Fig. 6). The concentrations of Fe were in the ranged of 80.1-140.0 ppm found in most of the area of Faridpur Sadar, Madhukhali, Nagarkanda, Bhanga, Sadarpur and whole of Char Bhadrasan upazila. On the other hand, the lowest Fe concentrations were found in the smaller area of the Faridpur Sadar, Sadarpur, Bhanga, Nagarkanda and Boalmari upazila which ranged from $<0.80 \mathrm{ppm}$ (Fig. 6). Iron concentrations ranged from 140.1-200.0 ppm were found in most of the areas of
Boalmari and some part of Nagarkanda, Alfadanga and Bhanga upazila (Fig. 6). The very high level of Fe concentration in the research area mainly results from weathering of iron ores (Koc and Deger, 1991). Iron is also accumulated in soils of the study area from the underground irrigation water abstracted from shallow and deep aquifer by shallow and deep tube-wells. The high levels of iron in soils might be a problem for phosphorus acquisition by crops. Phosphorus applied or inherent soil phosphorus may react with iron and transformed into complex iron-phosphate that make phosphorus unavailable for crops.

The manganese concentrations varied from 10 to 129 $\mathrm{mg} \mathrm{kg}$ with an average value of $58 \mathrm{ppm}$ where minimum and maximum values were observed in soils of Sadarpur and Madhukhali upazila, respectively (Table 1 and 2). As per soil fertility ranking (BARC, 2012) manganese contents are considered very high 
when its concentrations exceeded $3.75 \mathrm{ppm}$. The presence of high levels of $\mathrm{Fe}$ and $\mathrm{Mn}$ in soils of the region might reduced the availability of soil phosphorus for plant uptake because insoluble complex formation of $\mathrm{P}$ with $\mathrm{Fe}$ and $\mathrm{Mn}$. The highest concentration of $\mathrm{Mn}$ was found in a small area of western part of Madhukhali, northern part of Boalmari and southwestern part of Nagarkanda upazila with the range of greater than 80.0 ppm (Fig. 7). On the other hand, the lowest concentration of $\mathrm{Mn}$ was found in the eastern part of Sadarpur and a very small part of Faridpur Sadar upazila with the range of $<40 \mathrm{ppm}$ (Fig. 7). The soils of the whole area of Char Bhadrasan, a greater part of
Faridpur, Sadarpur, Boalmari and some part of Bhanga upazila contain Mn ranged from 40.1-60 ppm (Fig. 7). The spatial diversities of $\mathrm{Mn}$ in the study area are comparatively small, differing from the other elements. The spatial distributions of $\mathrm{Mn}$ in the study area are mainly controlled by natural factors. Manganese may be derived from industrial sources, although several studies have shown the elevated Mn concentration in soil mainly attributed to natural sources (Wang and Qin, 2007). The elevated amount of Mn may react with $P$ and form complexes which ultimately resulted to obligatory deficiency of $\mathrm{P}$ in soils.

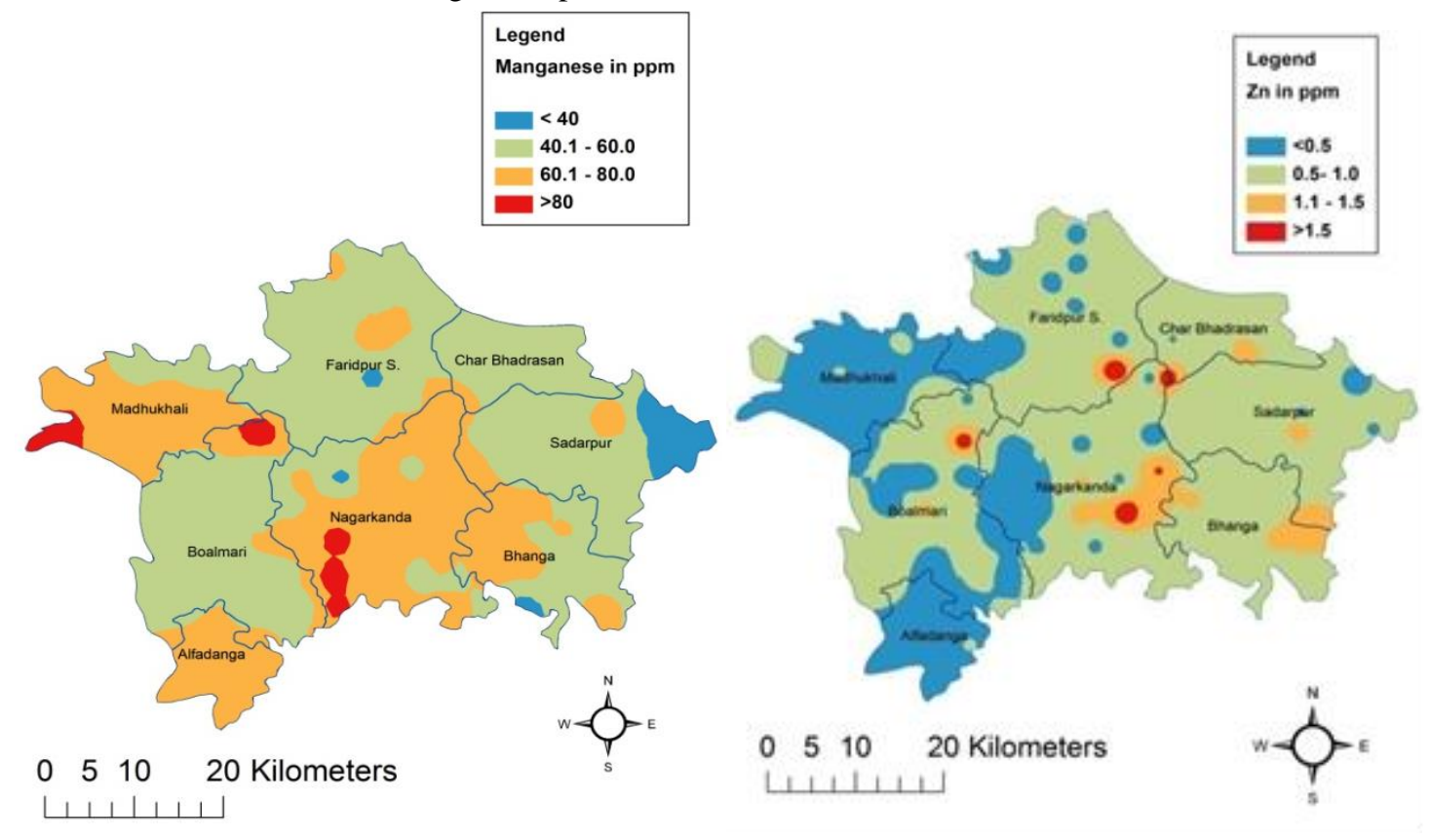

Fig.7. Spatial distribution of Manganese in soils of Faridpur district Fig. 8. Spatial distribution of Zinc in soils of Faridpur district

The concentrations of zinc did not follow the trends as observed in case of other nutrients. Zinc contents varied from 0.12 to $2.2 \mathrm{ppm}$ with an average value of 0.65 ppm where minimum and maximum values were observed in soils of Nagarkanda and Faridpur Sadar upazila, respectively (Table 1 and 2). Zinc status is considered very low and very high when its concentrations are below 0.45 and above $2.45 \mathrm{ppm}$, respectively (BARC, 2012). Therefore, zinc status of the Low Ganges River Floodplain soils were found very low to high. The lowest $\mathrm{Zn}$ concentration was found $<0.5 \mathrm{ppm}$ in the whole area of Madhukhali and Alfadanga and a greater part of Nagarkanda, some part of Boalmari and Faridpur Sadar upazila (Fig. 8) These areas are under medium high land and $\mathrm{Zn}$ moved towards the lower elevation through surface runoff and therefore, $\mathrm{Zn}$ concentration was found low. The low $\mathrm{Zn}$ concentration may be due to high $\mathrm{pH}$ in the study area as well. The highest $\mathrm{Zn}$ concentration was found in small area of Nagarkanda, Faridpur Sadar and Boalmari upazilas where the land types are medium low and during monsoon run off of $\mathrm{Zn}$ occurred from the ridge area and deposit in the basin area and thus soil becomes enriched with $\mathrm{Zn}$. The $\mathrm{Zn}$ concentration with the range of 0.5-1.0 ppm was found in most of the area of Faridpur Sadar, Sadarpur, Bhanga, Nagarkanda, Char Bhadrasan and Boalmari upazilas. The $\mathrm{Zn}$ concentration with the range of 1.1-1.5 ppm was found in some eastern part of Nagarkanda and Bhanga upazilas and very small area of Faridpur sadar, Sadarpur, Bhanga, Nagarkanda,Char Bhadrasan and Boalmari upazila. The availability of $\mathrm{Zn}$ in soils depends on $\mathrm{pH}$, organic matter, organic nad inorganic colloids and other physicchemical and biological conditions in the root zone. Land use practices and soil type may bring the heterogeneity in distribution of $\mathrm{Zn}$ in soils. Zinc is generally more available to plants in acid soils, while its availability decreases with the increased soil $\mathrm{pH}$. Most $\mathrm{pH}$-induced $\mathrm{Zn}$ deficiencies occur in neutral and calcareous soils, although not all these soils exhibit $\mathrm{Zn}$ deficiency because of increased availability from chelation of $\mathrm{Zn}$. At high $\mathrm{pH}, \mathrm{Zn}$ precipitates in soils as insoluble amorphous which reduces $\mathrm{Zn}$ availability in soil. Other metal cations i.e. $\mathrm{Cu}^{2+}, \mathrm{Fe}^{2+}$ and $\mathrm{Mn}^{2+}$ may 
inhibit $\mathrm{Zn}^{2+}$ uptake by plants, possibly because of competition for the same carrier site. High $\mathrm{P}$ availability can induce $\mathrm{Zn}$ deficiency by the formation of zincphosphate complex.

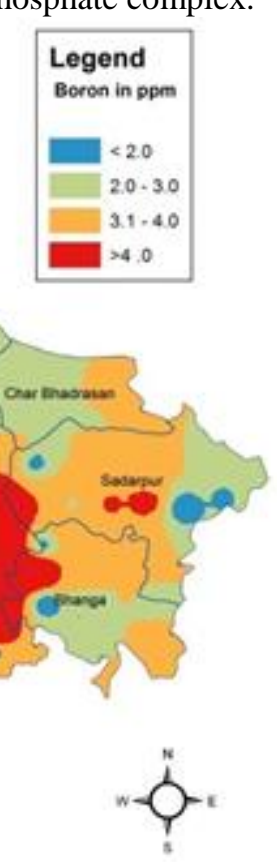

Fig. 9. Spatial distribution of Boron in soils of Faridpur district

Boron concentrations varied from 0.5 to $9.05 \mathrm{ppm}$ with an average value of $3.6 \mathrm{ppm}$ where both minimum and maximum values were observed in soils of Bhanga upazila (Table 1 and 2). Like copper, boron status followed the same range in fertility ranking i.e. it is very high when boron content is above $0.75 \mathrm{ppm}$. The highest concentration of B (>4.0 ppm) was found in the western and eastern part of Nagarkanda, eastern part of Boalmari southern part of Alfadanga, middle part of Madhukhali and a small area in Sadarpur upazila (Fig. 9). While the lowest B concentration $(<2.0 \mathrm{ppm})$ was found in some part of Sadarpur, a small part of Bhanga and a very small part of Faridpur sadar upazila (Fig. 9). Boron concentration 2.0-3.0 ppm was found in the greater area of Faridpur Sadar, Char Badrasan, Bhanga and Sadarpur upazila. The overall B concentration was very high in the whole study area.

\section{Pollution index}

The pollution indexes of $\mathrm{Cu}, \mathrm{Fe}, \mathrm{Mn}$ and $\mathrm{Zn}$ were ranged from $0.03-0.22,0.01-0.08,0.10-1.29$ and $0.001-$ 0.03 respectively (Table 1 ). It was observed that except $\mathrm{Mn}$, the loading indexes of other three metals were far below from the level $(\leq 1)$ to be considered as minimum pollution. Therefore, though the present levels of concentration of $\mathrm{Cu}, \mathrm{Fe}$ and $\mathrm{Zn}$ in soils of the Low Ganges River Floodplain areas are higher in terms of soil fertility, but much lower in terms of soil pollution. The concentration of $\mathrm{Mn}$ in the major part of study area attributed to medium pollution. The concentrations of $\mathrm{Mn}$ in soils of Alfadanga, Nagarkanda, Bhanga and Madhukhali upazilas were found very high and contributed to increase pollution index.

\section{Conclusions}

The Low Ganges River Floodplain comprises typical meander landscape of broad ridges and basins. Soils of the study area are calcareous in nature having neutral to alkaline in reaction. Organic carbon contents were found very low to low in ridges and medium to very high in basin areas. The concentrations of $\mathrm{Cu}, \mathrm{Fe}, \mathrm{Mn}$, $\mathrm{Zn}$ and $\mathrm{B}$ in soils were ranged from $0.80-6.80 \mathrm{ppm}, 24$ $295 \mathrm{ppm}, 10-129 \mathrm{ppm}, 0.12-2.20 \mathrm{ppm}$ and 0.5-9.05 ppm, respectively. As per soil fertility ranking $\mathrm{Cu}, \mathrm{Fe}$ and $\mathrm{Mn}$ contents are rated as very high, $\mathrm{Zn}$ very low to high and B optimum to very high. The pollution indexes of $\mathrm{Cu}, \mathrm{Fe}, \mathrm{Mn}$ and $\mathrm{Zn}$ were ranged from 0.03-0.22, $0.01-0.08,0.10-1.29$ and $0.001-0.03$, respectively. It was observed that except $\mathrm{Mn}$, the loading indexes of other three metals were far below from the minimum level $(\leq 1)$ to be considered as least pollution. The pollution indexes revealed that only Mn may exhibit a risk for environmental pollution. The concentrations of trace metals, $\mathrm{pH}$ and organic carbon in surface soil of the study area displayed a significant spatial diversity and distribution maps might be useful for different stakeholders for sustainable agriculture.

\section{References}

BARC. 2012. Fertilizer Recommendation Guide. Bangladesh Agricultural Research Council (BARC), Farmgate, New airport road, Dhaka-1215.

Brammer, H. 2012. The Physical Geography of Bangladesh. The University Press Limited, Red Crescent, House 61, Motijheel C/A, P.O. Box 2611, Dhaka 1000, Bangladesh.

Bityutskii, N. P.; Kaidun, P. I. and Yakkonen, K. L. 2012. The earthworm ( ) primes the release of 
mobile and available micronutrients in soil. Pedobiologia, 55(2): 93-99.

Bowen, H. J. M. 1966. Trace Elements in Biochemistry. Academic Press, New York.

Cheng, B. Y.; Fang, W. T.; Shyu, G. S. and Chang, T. K. 2013. Distribution of heavy metals in the sediments of agricultural fields adjacent to urban areas in Central Taiwan. Paddy Water Environ., 11: 343-351.

Chen, T. B.; Zheng, Y. M.; Lei, M.; Huang, Z. C.; Wu, H. T. and Chen, H. 2005. Assessment of heavy metal pollution in surface soils of urban parks in Beijing, China. Chemosphere, 60(4): 542-551.

CNEMC. 1990. The background values of Chinese soils. China National Environmental Monitoring Centre, Environmental Science Press of China, Beijing. 67-85.

Franzluebbers, G.; Ordoonez, A. and Loredo, J. 2010. Investigation of trace element sources from an industrialized area (Aviles, northern Spain) using multivariate statistical methods. Environ. Int., 27: 589-596.

Halim, H. and Wenb, G. 2003. Trace elements in soils. First ed. John Wiley \& Sons Ltd, The Atrium, Southern Gate, Chichester, West Sussex, PO19 8SQ, United Kingdom.

Hutchinson, T. C.; Fedorenko, A.; Fitchko, J.; Kuja, A.; Van Loon, J. and Lichwa, J. 1988. Movement and compartmentation of nickel and copper in an aquatic ecosystem. (In D.D. Hemphill (Ed.), Trace Substances in Environmental Health (pp 89-105), University of Missouri Press, Columbia).

Islam, A. 1992. Review of soil fertility research in Bangladesh. (In M. S. Hussain et al. (Eds.), Improving soil management for intensive cropping in the Tropics and Subtropics, 37(1-18).

Jenny, H. 1941. Factors of soil formation: A system of quantitative pedology by Hans Jenny. McGraw-Hill, New York.

Koc, T.; Deger, R.; Zhang, F. R.; Wei, Q.; Xu, Y. and Hui, J. G. 2003. Influence of land use change on soil nutrients in an intensive agricultural region of North China. Soil Till. Res., 88: 85-94.

Krishna, A. K. and Govil, P. K. 2008. Assessment of heavy metal contamination in soils around Manali industrial area, Chennai, Southern India. Environ. Geol., 54: 1465-1472.

Li, X. and Feng, L. 2010. Spatial distribution of hazardous elements in urban top soils surrounding Xi'an industrial areas, (NW China): controlling factors and contamination assessments. J. Hazard. Mater., 174: 662-669.

Matheron, G. 1963. Principles of geostatistics. Economic Geology, 58: 1246-1266.

McGrath, D. and Zhang, C. S. 2003. Spatial distribution of soil organic carbon concentrations in grassland of Ireland. Appl. Geochem., 18: 1629-1639.
Page, A. L.; Miller, R. H. and Keeney, D. R. 1982. Methods of Soil Analysis. $2^{\text {nd }}$ Edn., American Society of Agronomy, Madison, WI, USA.

Rezaei, S. A. and Gilkes, R. J. 2005. The effects of landscape attributes and plant community on soil chemical properties in rangelands. Geoderma, 125: 167-176.

Saldana, A.; Stein, A. and Zinck, J. A. 1998. Spatial variability of soil properties at different scales within three terraces of the Henare River (Spain). Catena, 33: 139-153.

Sauve, S.; McBride, M. B.; Norvell, W. A. and Hendershot, W.H. 1997. Copper solubility and speciation of in situ contaminated soils: Effects of copper level, $\mathrm{pH}$ and organic matter. Water Air Soil Pollut., 100: 133-149.

Sepaskhah, A. R.; Ahmadi, S. H.; Nikbakhtand, A. R. and Shahbazi. 2005. Geostatistical analysis of sorptivity for a soil under tilled and no-tilled conditions. Soil Till. Res., 83: 237-245.

Silva, D. 1996. Background concentrations of trace and major elements in California soils. Kearney Foundation of Soil Science, Division of Agriculture and Natural Resources, University of California. UCR Publications.

Singh, K.; Mohan, D.; Singh, V. and Malik, A. 2005. Studies on distribution and fractionation of heavy metals in Gomti river sediments - a tributary of the Ganges. Indian J. Hydrol., 312: 14-27.

Wandruszka, W. 2006. Phosphorus retention in calcareous soils and the effect of organic matter on its mobility. Geochem. Trans., 7(6): 1-8.

Wang, X. S. and Qin, Y. 2007. Some characteristics of the distribution of heavy metals in urban topsoil of Xuzhou, China. Environ. Geochem. Health, 29: 1119.

Webster, R. and Oliver, M. 2001. Geostatistics for environmental scientists. John Wiley and Sons, Chichester.

Wu, Y.; Xu, Y.; Zhang, J.; Hu, S. and Liu, K. 2011. Heavy metals pollution and the identification of their sources in soil over Xiaoqinlinggold-mining region, Shaanxi, China. Environ. Earth Sci., 64: 1585-1592.

Zhang, C. S. and McGrath, D. 2005. Geostatistical and GIS analyses on soil organic carbon concentrations in grassland of southeastern Ireland from two different periods. Geoderma, 119: 261-275.

Zhang, C. S. 2006. Using multivariate analyses and GIS to identify pollutants and their spatial patterns in urban soils in Galway, Ireland. Environ. Pollut., 142: 501-511.

Wei, B. G. and Yang, L. S. 2010. A review of heavy metal contaminations in urban soils, urban road dusts and agricultural soils from China. Microchem. J., 94(2): 99-107. 